\title{
Effects of Short-Term Set-Aside Management Practices on Soil Microorganism and Enzyme Activity in China
}

\author{
Guangyu $\mathrm{Li}^{1,2}$ (1) and Cifang $\mathrm{Wu}^{1,2, *}$ \\ 1 Institute of Land Science and Property Management, School of Public Affairs, Zhejiang University, \\ Hangzhou 310058, China; sethlee0010@yahoo.com \\ 2 Land Academy for National Development, Zhejiang University, Hangzhou 310058, China \\ * Correspondence: wucifang@zju.edu.cn
}

Received: 13 July 2017; Accepted: 10 August 2017; Published: 14 August 2017

\begin{abstract}
Set-aside farmland can effectively improve the self-rehabilitation of arable soil. Long-term set-asides however cannot satisfy provisionment, therefore the use of short-term set-asides to restore cultivated soil is a better option. Few studies have compared short-term set-aside patterns, and the effects of set-asides on soil microbial community and enzyme enzymes. We analyzed the bacterial structure, microbial biomass carbon/nitrogen and enzyme activity of farmland soil under different set-aside regimes in the Yellow River Delta of China. Bacterial alpha diversity was relatively lower under only irrigation, and farmyard manure applications showed clear advantages. Set-asides should consider their influence on soil organic carbon and nitrogen, which were correlated with microbial community structure. Nitrospira (0.47-1.67\%), Acidobacteria Gp6 (8.26-15.91\%) and unclassified Burkholderiales $(1.50-2.81 \%)$ were significantly altered $(p<0.01)$. Based on functions of these genera, some set-aside patterns led to a relative balance in nitrogen and carbon turnover. Partial treatments showed a deficiency in organic matter. In addition, farmyard manure may lead to the increased consumption of organic matter, with the exception of native plants set-asides. Conventional farming (control group) displayed a significant enzyme activity advantage. Set-aside management practices guided soil microbial communities to different states. Integrated soil microbiota and the content of carbon and nitrogen, native plants with farmyard manure showed an equilibrium state relatively, which would be helpful to improve land quality in the short-term.
\end{abstract}

Keywords: set-aside patterns; microbial communities; microbial biomass carbon; farmyard manure; soil enzyme

\section{Introduction}

According to the Ministry of Land and Resources of the People's Republic of China, approximately $2.67 \%$ of the arable land in China is in excellent condition based on the Chinese standard "Regulation for gradation on agriculture land quality" (GB/T 28407-2012) defining soil fertility, productivity, irrigation, etc. [1]. Increasing amounts of chemical inputs (herbicides and fertilizers) are available to provide stable farm incomes in areas with formerly poor environmental conditions [2]. However, water and soil erosion of arable land results from this behavior, and organic matter quality and quantity becomes degraded. The degradation of organic matter destroys the soil microarea, and threatens microorganism survival [3]. A growing number of scientists, farmers and the general public fear for the long-term sustainability of such highly input-dependent and ecologically simplified food production systems [4]. To improve farmland ecosystems, the European Union (EU) proposed in 1992 a set-aside programme, which is part of the Common Agricultural Policy (CAP) [5]. Regarding long-term set-aside, the Chinese government implemented the Grain for Green programme in 1999 [6]. However, 
due to increasing human needs for land, restoring large areas of farmland to forest or grassland is unrealistic [7]. Short-term set-aside projects are more suitable for China, but remain immature.

The relevant studies on set-asides in China have mainly focused on rotation crop, no-tillage, rotation tillage and barely fallow practices. We designed valid set-aside methods according to ecological intensification based on agronomic knowledge, plant science and agricultural management [8-10]. Therefore, three types of set-aside methods were established: (i) intercropping and mixed sowing instead of monoculture [11]; (ii) changing the crops on arable land; (iii) improving the management of farmland and relieving the pressure of traditional farming.

The health of arable land is closely linked to soil microbial properties [12], and the capability of cultivated land is significantly correlated with microbial biomass carbon (MBC) and microbial biomass nitrogen (MBN) [13]. Microbial diversity and enzyme activity can reflect the type of tillage, type of crop, input of nitrogen fertilizer and effect of land reclamation [14,15]. Microbial diversity and enzyme activity have also been used to assess soil quality in contaminated soils [16]; therefore, they could represent important indexes for evaluating the sustainable development of cultivated land. Some scholars have proposed that soil biodiversity is crucial to agro-ecosystems and thus should be included in the scope of management decision-making [17].

Determining the eco-efficiency of set-aside farmland with respect to soil microbiology is necessary. We used a soil microbial method to study the mechanism of different set-aside methods on the microbial community structure and enzyme activity. Our results addressed: (i) the short-term effects of different set-asides on soil microbes and (ii) the choice of a suitable set-aside method.

\section{Methods}

\subsection{Site Description and Experimental Design}

The study site was located at the Shandong Wudi Field Scientific Observation and Research Base for Land Use, in Binzhou, China (E $117^{\circ} 43^{\prime}, \mathrm{N} 37^{\circ} 48^{\prime}$, altitude of $5 \mathrm{~m}$ above sea level). The soil was approximately $5 \%$ clay and $75 \%$ silt; it is derived from diluvial sediments of the Yellow River and is classified as a typical saline alluvial soil (Fluvisols, per the Food and Agriculture Organization). According to the local agricultural bureaus, sorghum has been conventionally planted for 5 years (sown in April, harvested in October and fallow in winter), but the planting area decreased markedly where partial farmland (45\%) nearby was already or nearly abandoned, grown with other crops or changed to water areas. The experiments were set up in May 2015 and concluded in May 2016, on flat and relatively homogeneous farmland.

The topsoil (0-20-cm layer) chemical properties were as follows: electrical conductivity (EC) of $1.8 \mu \mathrm{S} / \mathrm{m}$, total nitrogen (TN) of $0.62 \mathrm{~g} / \mathrm{kg}$, soil organic carbon (SOC) of $8.39 \mathrm{~g} / \mathrm{kg}$, available nitrogen (AN) of $24.59 \mathrm{mg} / \mathrm{kg}$, available potassium (AK) of $0.11 \mathrm{mg} / \mathrm{kg}$, available phosphorus (AP) of $8.51 \mathrm{mg} / \mathrm{kg}$, and a $\mathrm{pH}$ of 8.43 .

We chose soybean (Glycine max (Linn.) Merr.), maize (Zea mays L.), alfalfa (Medicago sativa L.), dahurian wild rye (Elymus dahuricus Turcz.) and native plants after combining the opinions of the local agriculture sectors, an investigation of local cultivation customs and farmer preferences and the benefits of both mixed seeds and intercropping of leguminous and gramineous plants [18]. The vegetation types in conjunction with three management regimes formed 15 set-aside patterns and a control treatment; relevant abbreviations are shown in Table 1. Each pattern was replicated three times, for a total of 48 plots $\left(5 \times 6 \mathrm{~m}^{2}\right.$ each) that were randomly distributed (more than $1 \mathrm{~m}$ interval each for a total area of 2.6 ha). Management treatments began 5 May 2015 and continued for 1 year. Treatment details were as follows: (i) no management (N1-N5), in which no other labour except surface weeding occurred to ensure the emergence of plants (N2-N5); (ii) irrigation only (I1-I5), in which irrigation occurred on 13 May 2015 using water from nearby rivers (the irrigation amount was calculated using the ETo calculator version 3.1 (developed by the FAO http:/ / www.fao.org/nr/water/eto.html)) and I2-I5 treatments were surface-weeded; (iii) organic manure and irrigation (O1-O5), in which both 
cow manure (1500 kg/ha) and irrigation were applied and O2-O5 treatments were surface-weeded; and (iv) control group (CK), in which conventional sorghum planting occurred alongside tilling and simultaneous flood irrigation applications as well as chemical fertilizer (urea and inorganic fertilizer (NPK) for a total of $330 \mathrm{~kg} / \mathrm{ha}$ ). Based on (i) to (iii), we chose the intercropping sowing method to guarantee feasibility.

Table 1. Treatments applied for set-aside.

\begin{tabular}{ccccc}
\hline \multirow{2}{*}{ Vegetation } & \multicolumn{4}{c}{ Management Groups } \\
\cline { 2 - 5 } & $\begin{array}{c}\text { No Management } \\
\text { (N) }\end{array}$ & Irrigation (I) & $\begin{array}{c}\text { Organic Manure } \\
\text { and Irrigation (O) }\end{array}$ & $\begin{array}{c}\text { Control } \\
\text { Group (CK) }\end{array}$ \\
\hline Native plants (1) & $\mathrm{N} 1$ & $\mathrm{I} 1$ & $\mathrm{O} 1$ & $\mathrm{n}$ \\
Soybean-maize (2) & $\mathrm{N} 2$ & $\mathrm{I} 2$ & $\mathrm{O} 2$ & $\mathrm{n}$ \\
Soybean-dahurian wild rye (3) & $\mathrm{N} 3$ & $\mathrm{I}$ & $\mathrm{O} 3$ & $\mathrm{n}$ \\
Alfalfa-maize (4) & $\mathrm{N} 4$ & $\mathrm{I}$ & $\mathrm{O} 4$ & $\mathrm{n}$ \\
Alfalfa-dahurian wild rye (5) & $\mathrm{N} 5$ & $\mathrm{I} 5$ & $\mathrm{n}$ & $\mathrm{CK}$ \\
Control group (CK) & $\mathrm{n}$ & $\mathrm{n}$ &
\end{tabular}

\subsection{Soil Sampling and Preparation}

The treatments began 5 May 2015. On 10 June 2016, we completed soil sampling. According to the "S" sampling principle, we collected soil samples from six points at a depth of $0-20 \mathrm{~cm}$ from each plot using a foil sampler. Afterward, the samples were mixed and homogenized and half of the remaining soil was passed through a $<2 \mathrm{~mm}$ sieve to remove aboveground plant material, roots, and stones and stored at $-40{ }^{\circ} \mathrm{C}$ prior to analysis. Soil DNA extraction was completed in 1 week, and the extracts were stored at $-20{ }^{\circ} \mathrm{C}$ until further use. Soil enzyme activity was assayed in 2 weeks. A portion of each soil sample was air-dried, to measure physical and chemical properties.

\subsection{Measurements of Soil Physicochemical Property}

Soil organic carbon (SOC) and total nitrogen (TN) content were determined on air dried, finely ground soil aliquots. Subsamples of $10 \mathrm{mg}$ were weighted into tin caps and analyzed by a $\mathrm{CN}$ analyzer (TOC-L Analyzer and TN Unit, Shimadzu, Kyoto, Japan).

\subsection{Biological Analysis}

\subsubsection{DNA Extraction and MiSeq Illumina Sequencing}

Soil total genomic DNA was extracted from $0.5 \mathrm{~g}$ of soil sample using a PowerSoil Total DNA Isolation Kit (MoBio Labs, Solana Beach, CA, USA) according to the manufacturer's instruction. DNA concentration and quality were checked using a NanoDrop spectrophotometer (NanoDrop Technologies Inc., Wilmington, DE, USA). Extracted DNA was diluted to $10 \mathrm{ng} / \mu \mathrm{L}$ and stored at $-40{ }^{\circ} \mathrm{C}$ for downstream use.

The primer pair 515F (5'-GTGCCAGCMGCCGCGG-3') and reverse primer 907R (5'-CCGTCAATTCMTTTRAGTT-3') with unique $6 \mathrm{nt}$ barcode was used to amplify the hypervariable V4 region [19]. The sequencing samples were prepared using TruSeq DNA kit (Illumina, San Diago, CA, USA) according to manufacturer's instructions. The purified library was diluted, denatured, re-diluted, mixed with PhiX (equal to 30\% of final DNA amount) as described in the Illumina library preparation protocols, and then applied to a Miseq system (Illumina, San Diago, CA, USA) for sequencing with the Reagent Kit v2 $2 \times 250$ bp (Illumina, San Diago, CA, USA) as described in the manufacturer's manual. 


\subsubsection{Sequencing Data Processing}

Processing of the raw sequences obtained through Illumina sequencing was performed using the Quantitative Insights into Microbial Ecology (QIIME) pipeline (Knight Lab, Boulder, CT, USA) (QIIME: an pipeline for performing microbiome analysis). We assembled paired-end reads using FLASH. Reads with quality score lower than 20, ambiguous bases and improper primers were discarded before clustering. The resultant high quality sequences were then clustered into operational taxonomic units (OTUs) at 97\% similarity using UPARSE algorithm. Simultaneously, chimeras were checked and eliminated during clustering. Taxonomic classification of representative sequences from individual OTU was performed by rdp classifier [20]. In order to compare relative difference between samples and retain the validity of most samples, a randomly selected subset of 7200 sequences per sample was performed for down-stream analyses. There were 1835534 high-quality sequences obtained, and sequence number of each sample was from 7599 to 101297 (Table S1).

\subsubsection{Soil Microbial Biomass}

The composited soils were divided into two parts: one was sieved to pass through a 2-mm mesh immediately and stored at $4{ }^{\circ} \mathrm{C}$ until analysis for the estimation of microbial biomass carbon (MBC) and microbial biomass nitrogen (MBN). Soil MBC and MBN were determined by the fumigation-extraction method [21,22]. The total organic carbon and nitrogen in the extracts were measured using a Multi N/C 3000 analyzer (Elementar Analysensysteme GmbH, Langenselbold, Germany).

MBC was calculated as:

$$
\mathrm{MBC}=\mathrm{EC} / \mathrm{k}_{\mathrm{EC}}
$$

where $\mathrm{EC}=($ organic $\mathrm{C}$ extracted from fumigated soils $)-($ organic $\mathrm{C}$ extracted from non-fumigated soils) and $\mathrm{k}_{\mathrm{EC}}=0.38$ [23].

MBN was calculated as:

$$
\mathrm{MBN}=\mathrm{EN} / \mathrm{k}_{\mathrm{EN}}
$$

where $\mathrm{EN}=($ total $\mathrm{N}$ extracted from fumigated soils $)-($ total $\mathrm{N}$ extracted from non-fumigated soils $)$ and $\mathrm{k}_{\mathrm{EN}}=0.45[21]$.

\subsection{Soil Enzymes}

$\beta$-Glucosidase enzyme activity was measured as described by [24]. The $\beta$-glucosidase enzyme was expressed as PNP $\mu \mathrm{g} / \mathrm{g}, 1 \mathrm{~h}$. Urease activity was measured using the modified [25]. The ammonium

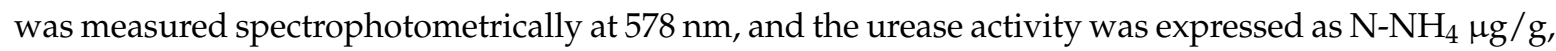
$1 \mathrm{~h}$. Alkaline phosphatase activity was determined according to [26].The alkaline phosphatase was expressed as phenol $\mu \mathrm{g} / \mathrm{g}, 1 \mathrm{~h}$. The activity of catalase was determined by UV-Vis spectrophotometer (PGENERAL, Beijing, China) because the hydrogen peroxide had a strong light absorption at $240 \mathrm{~nm}$. The catalase activity was calculated as the soilless control sample containing hydrogen peroxide minus the sum of the non-substrate control sample and the ordinary sample, and expressed as $\mathrm{H}_{2} \mathrm{O}_{2} \mu \mathrm{g} / \mathrm{g}$, $1 \mathrm{~h}$.

\subsection{Statistical Analyses}

The means and standard deviations of 3 replicates were calculated. The analysis of variance (ANOVA) was carried out using SPSS software package (version 13.0, IBM, New York, NY, USA). The significance of the parameters was tested using least significant difference (LSD) multiple range test at $p<0.05$ or $p<0.01$ after one-way ANOVA. The downstream analysis of soil DNA was performed using QIIME and R (Bell Laboratories, Murray Hill, NJ, USA) (R: A language and environment for statistical computing). Alpha diversity indices including the Shannon index and Chao1 index were calculated, and Bray-Curtis dissimilarity metrics were used for principle coordinate analysis 
(PCoA). Pearson correlation coefficients were calculated among soil basic chemical properties and enzyme activities.

\section{Results}

\subsection{Analysis of Microbial Community and Influencing Factors on Cultivated Land}

\subsubsection{Alpha Diversity of Soil Microbial Community}

Group O had the most observed operational taxonomic units (OTUs), followed by CK, N, and I (Table 2). O3 had the highest Shannon index of all the groups $(p<0.05)$, and I3 had the lowest $(p<0.05)$. There was a little difference in Simpson index among the set-asides, but I3 had the lowest $(p<0.01)$ (Table S2). I3 also displayed the lowest alpha diversity, in general. O3, O4 and O5 displayed significantly higher phylogenetic diversity (PD) whole tree values than did the other groups $(p<0.05)$, and I3 and N5 had significantly lower values compared with those of the other groups $(p<0.05)$. O3 and O5 displayed significantly higher Chao1 index values than did the other groups $(p<0.05)$, and N5 and I3 had significantly lower values compared with those of the other groups $(p<0.05)$. Among those groups, O3, O4 and O5 had significantly higher values than did the other groups $(p<0.05)$, and I3 had the lower values.

Table 2. Alpha diversity of soil microbial community.

\begin{tabular}{ccccc}
\hline Sample ID & Shannon Index & Observed_Otus & Chao1 Index & PD_Whole_Tree \\
\hline CK & $9.88 \pm 0.07_{a b c}$ & $1986.00 \pm 25.96_{a b c}$ & $3309.87 \pm 40.61_{a b c}$ & $111.25 \pm 2.11_{a b c}$ \\
N1 & $9.73 \pm 0.03_{b c d}$ & $1887.33 \pm 9.03_{c d e f}$ & $3201.78 \pm 132.00_{a b c d}$ & $105.46 \pm 0.80_{b c d}$ \\
N2 & $9.85 \pm 0.08_{a b c}$ & $1941.33 \pm 53.32_{b c d}$ & $3205.43 \pm 158.09_{a b c d}$ & $106.96 \pm 2.84_{b c d}$ \\
N3 & $9.73 \pm 0.09_{b c d}$ & $1929.67 \pm 41.49_{b c d}$ & $3200.35 \pm 113.72_{a b c d}$ & $106.74 \pm 3.00_{b c d}$ \\
N4 & $9.76 \pm 0.04_{a b c d}$ & $1858.67 \pm 38.42_{d e f}$ & $3051.08 \pm 78.06_{c d e}$ & $101.33 \pm 2.12_{d f}$ \\
N5 & $9.53 \pm 0.15_{d}$ & $1773.50 \pm 97.50_{f g}$ & $2871.64 \pm 141.33_{e}$ & $97.50 \pm 5.01_{f}$ \\
I1 & $9.61 \pm 0.07_{c d}$ & $1801.00 \pm 42.62_{e f g}$ & $2986.73 \pm 118.40_{d e}$ & $101.16 \pm 3.10_{d f}$ \\
I2 & $9.55 \pm 0.05_{d}$ & $1803.67 \pm 46.95_{e f g}$ & $3056.10 \pm 160.58_{c d e}$ & $101.38 \pm 3.14_{d f}$ \\
I3 & $9.23 \pm 0.43_{e}$ & $1714.50 \pm 139.50_{g}$ & $2866.69 \pm 315.44_{e}$ & $96.85 \pm 6.06_{f}$ \\
I4 & $9.73 \pm 0.10_{b c d}$ & $1896.67 \pm 60.81_{b c d e}$ & $3110.23 \pm 131.15_{b c d e}$ & $104.83 \pm 3.54_{c d}$ \\
I5 & $9.73 \pm 0.07_{b c d}$ & $1899.00 \pm 22.55_{b c d e}$ & $3149.99 \pm 101.43_{a b c d e}$ & $104.73 \pm 2.43_{c d}$ \\
O1 & $9.87 \pm 0.04_{a b c}$ & $2016.33 \pm 23.70_{a b}$ & $3271.84 \pm 59.80_{a b c d}$ & $112.05 \pm 1.11_{a b}$ \\
O2 & $9.89 \pm 0.04_{a b}$ & $2001.33 \pm 43.76_{a b c}$ & $3330.37 \pm 129.47_{a b c}$ & $111.52 \pm 2.65_{a b}$ \\
O3 & $10.02 \pm 0.03_{a}$ & $2088.67 \pm 20.76_{a}$ & $3463.42 \pm 13.08_{a}$ & $116.00 \pm 0.83_{a}$ \\
O4 & $9.98 \pm 0.03_{a b}$ & $2062.67 \pm 17.46_{a}$ & $3412.02 \pm 53.47_{a b}$ & $114.04 \pm 1.03_{a}$ \\
O5 & $9.10 \pm 0.02_{a b}$ & $2073.67 \pm 27.40_{a}$ & $3440.88 \pm 110.25_{a}$ & $115.26 \pm 0.60_{a}$ \\
\hline
\end{tabular}

Arrange letters $a, b, c, d$, e and f from large to small based on average values. Values in the same column followed by the same letter are not different $(p>0.05)$ according to a General Linear Model (GLM) protected least significant difference (LSD) test.

\subsubsection{Beta Diversity of Soil Microbial Community}

According to PCoA (Figure 1), CK was highly significantly different from the other groups $(p<0.01)$. Groups I and N were not significantly different, and intra-group differences were also not significant. First, $\mathrm{O} 3, \mathrm{O} 4$ and $\mathrm{O} 5$ did not significantly differ, but they did significantly differ from $\mathrm{O} 1$ and $\mathrm{O} 2(p<0.01)$. Group $\mathrm{O}$ was significantly different from group $\mathrm{N}$, except for $\mathrm{O} 1(p<0.01)$. There was no significant difference between $\mathrm{O} 1$ and $\mathrm{O} 2$. The microbial community of CK exhibited a scattered distribution until the beginning of set-aside treatments (Figure 1). 


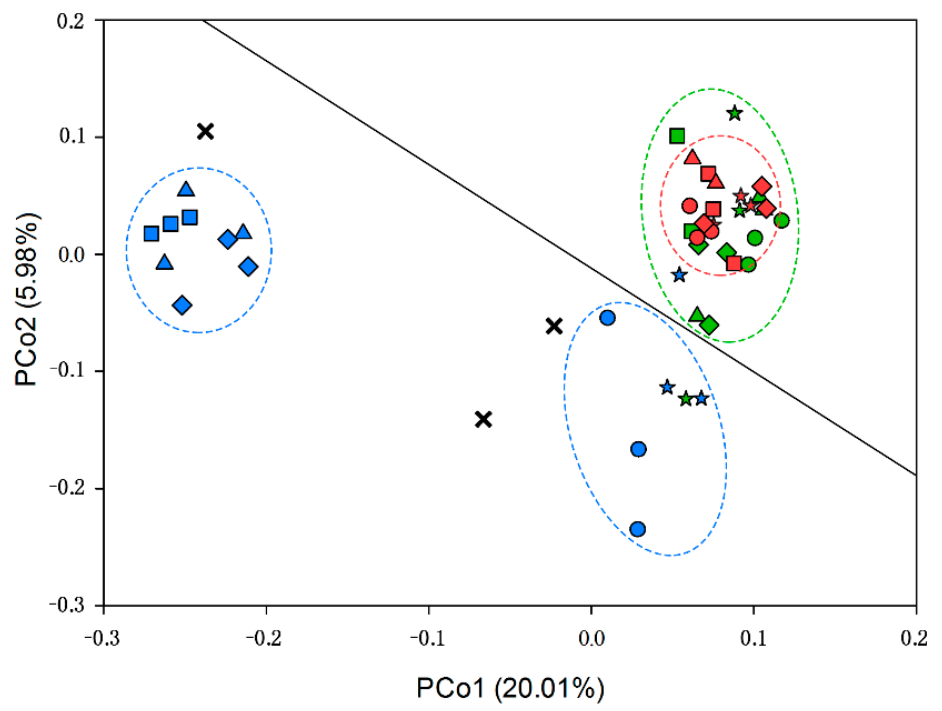

Figure 1. PCoA analysis of Bray-Curtis distance between samples. The points can be distinguished by color (management) and shape (plant types). Red indicated management group N; green represented group I; and blue indicated group $\mathrm{O}$. Control group was indicated by black cross " $\mathrm{X}$ ". Five-pointed star represented native plants; circular represented Soybean-Maize; square indicated Soybean-Elymus; triangle indicated Alfalfa-Maize; and diamond represented Alfalfa-Elymus. The black solid line, which divide the image into two parts, presented the fertilization status. The upper part of the black line indicated that no fertilizer was applied. In contrast, the lower part showed the application of fertilizer.

According to the redundancy analysis (RDA) (Figure 2), the proportion explaining RDA1 was $21.97 \%$; this proportion was greater than that for RDA2, which was $10.26 \%$. On the RDA axes, the relationships between environmental variables and the axes were determined by projection length on the RDA axis (arrow length and angle size).

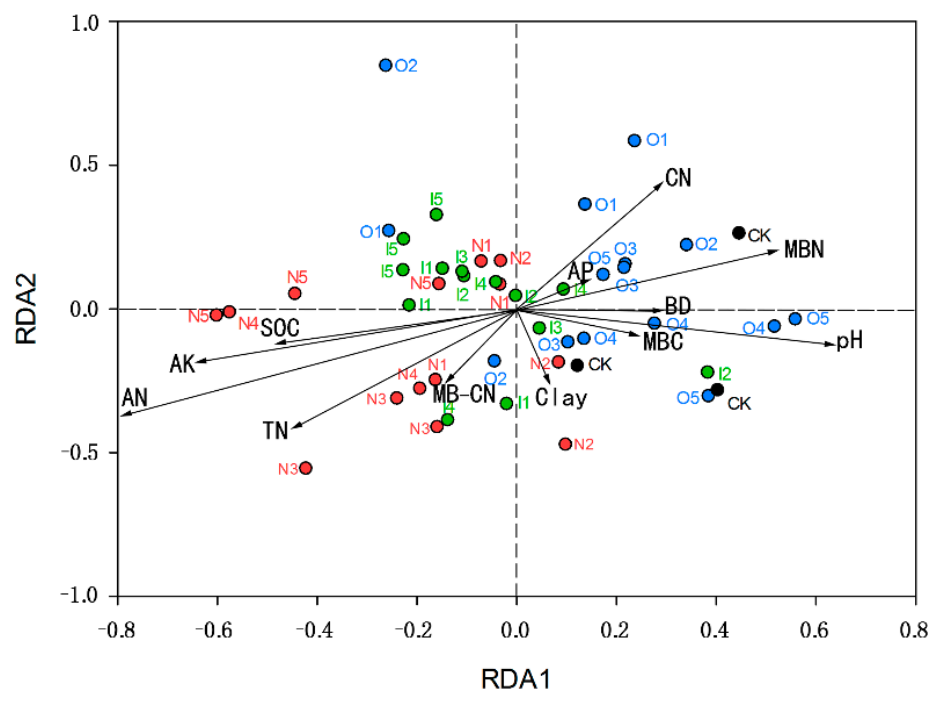

Figure 2. Redundancy analysis (RDA) of microbial communities using soil properties as environmental parameters. The different points color represents different management, which was consistent with Figure 1. The arrows represent soil properties, including carbon-nitrogen ratio ( $\mathrm{CN})$, available phosphorus (AP), microbial biomass nitrogen (MBN), bulk density (BD), microbial biomass carbon $(\mathrm{MBC})$, microbial biomass carbon-nitrogen ratio $(\mathrm{MB}-\mathrm{CN})$, total nitrogen $(\mathrm{TN})$, available nitrogen (AN), available potassium (AK), soil organic carbon (SOC). The circles were colored by managements, consistent with Figure 1. 
Black spots represent the $\mathrm{CK}$, distributed in the 1st and 4th quadrants. The $\mathrm{N}$ group is shown in red and mainly exists in the 2nd and 3rd quadrants (two points in the 1st and 4th quadrants). Group I is green and exists mainly in the 2nd and 3rd quadrants. Group $\mathrm{O}$ is blue and exists mainly in the 1st and 4th quadrants. The CK and group $\mathrm{O}$ are distributed on the right side of RDA2 axis, and $\mathrm{N}$ and $\mathrm{I}$ groups are mainly distributed on the left side of the RDA2 axis. The contents of AN, TN and AK were greater in the $\mathrm{N}$ group, and the group was influenced greatly. The $\mathrm{O}$ group had lower $\mathrm{AN}, \mathrm{TN}$ and $\mathrm{AK}$ contents and was little impacted.

\subsubsection{Microbial Community Structure}

A total of 457 genera were identified from these samples and used to study bacterial community structure. Figure 3 shows that set-aside treatments transformed the bacterial community structure. Many bacterial genera with greater relative percentages, such as Gp4 (4.16-7.10\%), Gp6 (8.26-15.91\%), Nitrospira (0.47-1.67\%), unclassified Comamonadaceae (0.80-2.61\%), unclassified Burkholderiales $(1.50-2.81 \%)$ and unclassified bacteria (10.67-14.73\%), were identified in farmland soils. Nitrospira in CK was significantly higher than in groups $\mathrm{N}$ and I, except I3 $(p<0.05)$, and group $\mathrm{N}$ had significantly less Nitrospira than did group $\mathrm{O}(p<0.05)$. Nitrospira of I2 and I3 did not significantly different from that of $\mathrm{O} 2$ and $\mathrm{O} 3$. The correlation of $\mathrm{Gp} 6$ and unclassified Burkholderiales was highly significant $(\mathrm{r}=0.740, p<0.001)$; at the same time, Gp6 and unclassified Burkholderiales were also significantly negatively correlated with Nitrospira $(p<0.001)$. CK, O3, O4 and O5 displayed significantly less Gp6 and unclassified Burkholderiales than did $\mathrm{O} 1$ and $\mathrm{O} 2(p<0.05)$.

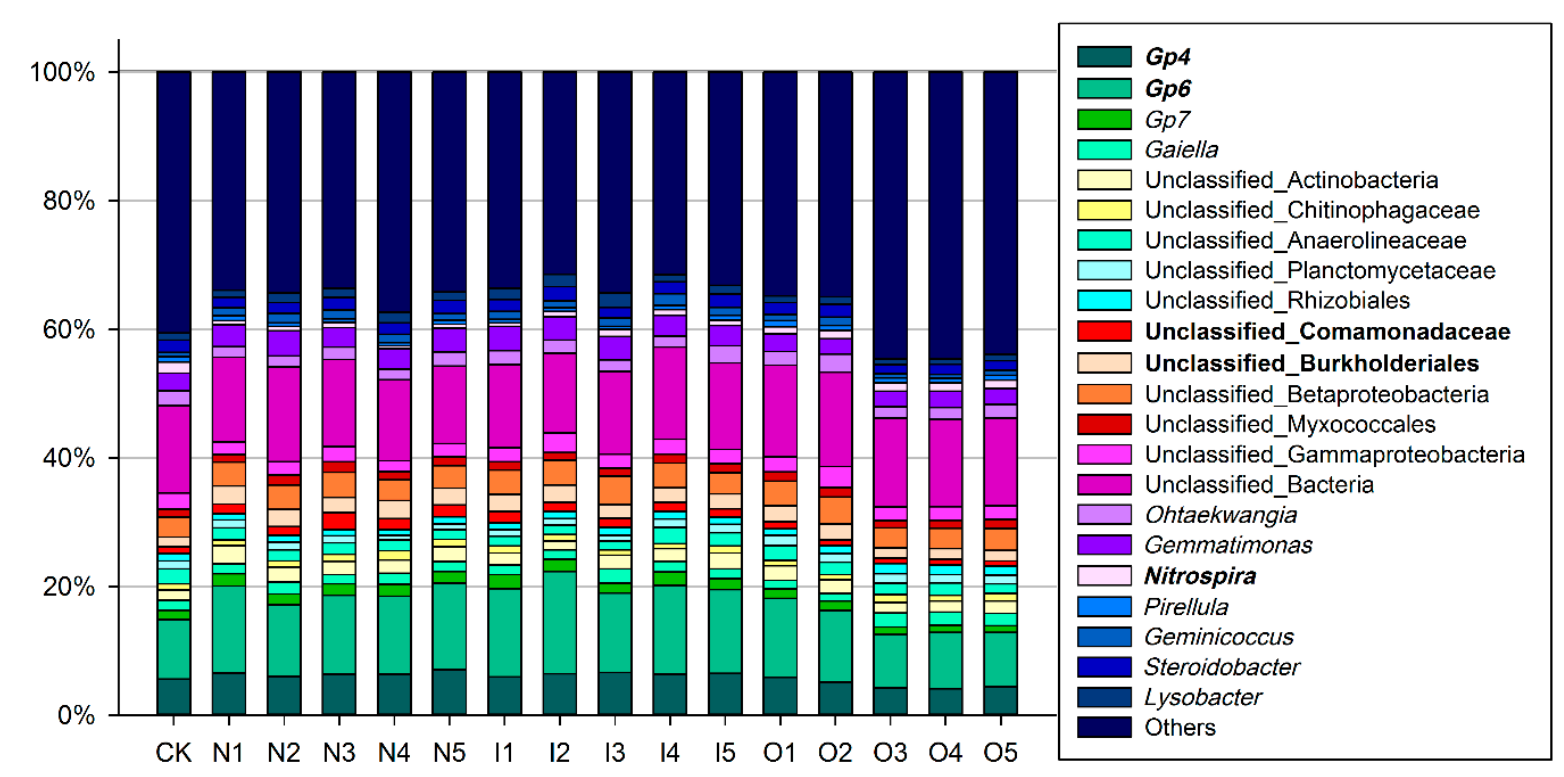

Figure 3. Relative abundance stacked bar plot of the microbial genera. The samples were summarized by management-plant types.

\subsection{Soil Microbial Biomass Carbon and Nitrogen}

The SOC among set-asides did not significantly differ (Table 3). The TN was highest in N2 $(p<0.05)$. The carbon/nitrogen ratio $(\mathrm{C} / \mathrm{N})$ of $\mathrm{N} 2(5.93)$ was the highest $(p<0.05)$; I5 was significantly higher than both O5 $(p<0.05)$ and CK. Group O had slightly higher MBC than did groups I and N; I1 had significantly less than O5 and N1 $(p<0.05)$. The microbial biomass $\mathrm{C} / \mathrm{N}$ was not consistent, but differences were not significant. CK had a higher proportion of MBC than did N2, N4, N5, I1 to $\mathrm{I} 3$, and $\mathrm{O} 1$, and the proportion in $\mathrm{N} 1(4.20 \%)$ was markedly higher than that in I1 and $\mathrm{O} 1(2.76 \%$ and $3.16 \%$, respectively). The effects of fertilizer on the proportion of MBN were more significant. 
Table 3. The change of soil carbon and nitrogen of arable lands in spring.

\begin{tabular}{|c|c|c|c|c|c|c|c|c|}
\hline \multirow{2}{*}{$\begin{array}{l}\text { Sample } \\
\text { ID }\end{array}$} & SOC & Soil TN & \multirow{2}{*}{$\begin{array}{c}\text { C-to-N } \\
\text { Ratio of Soil }\end{array}$} & MBC & MBN & \multirow{2}{*}{$\begin{array}{c}\text { MBC-to-MBN } \\
\text { Ratio }\end{array}$} & \multicolumn{2}{|c|}{$\begin{array}{c}\% \text { of Total C } \\
\text { or } \mathrm{N} \text { as }\end{array}$} \\
\hline & \multicolumn{2}{|c|}{ (g/kg) } & & \multicolumn{2}{|c|}{ (mg/kg) } & & MBC & MBN \\
\hline CK & 5.74 & $0.80_{b}$ & $7.17_{a b c}$ & $256.48_{a b c}$ & $20.51_{a b}$ & 12.56 & 4.47 & 3.61 \\
\hline N1 & 5.50 & $0.90_{b}$ & $6.14_{a b c}$ & $293.86_{a b}$ & $20.88_{a b}$ & 14.34 & 5.34 & 3.67 \\
\hline N2 & 5.89 & $1.36_{a}$ & $4.64_{\mathcal{C}}$ & $249.82_{a b c}$ & $18.60_{a b}$ & 13.67 & 4.24 & 2.80 \\
\hline N3 & 5.28 & $0.95_{b}$ & $5.53_{b c}$ & $256.30_{a b c}$ & $17.60_{b}$ & 14.55 & 4.85 & 2.50 \\
\hline N4 & 5.32 & $1.00_{b}$ & $5.43_{b c}$ & $241.32_{a b c}$ & $16.43_{b}$ & 14.86 & 4.54 & 2.09 \\
\hline N5 & 5.23 & $0.86_{b}$ & $6.08_{a b c}$ & $226.64_{b c}$ & $21.19_{a b}$ & 11.21 & 4.33 & 3.30 \\
\hline I1 & 6.01 & $0.78_{b}$ & $7.74_{a b}$ & $219.12_{c}$ & $21.02_{a b}$ & 12.66 & 3.65 & 3.10 \\
\hline $\mathrm{I} 2$ & 6.36 & $0.96_{b}$ & $6.63_{a b c}$ & $268.66_{a b c}$ & $22.37_{a b}$ & 12.27 & 4.22 & 2.98 \\
\hline $\mathrm{I} 3$ & 5.92 & $0.92_{b}$ & $6.43_{a b c}$ & $225.88_{b c}$ & $20.22_{a b}$ & 11.37 & 3.82 & 3.05 \\
\hline $\mathrm{I} 4$ & 6.02 & $0.86_{b}$ & $7.01_{a b c}$ & $268.93_{a b c}$ & $19.10_{a b}$ & 14.33 & 4.47 & 3.09 \\
\hline I5 & 5.29 & $0.71_{b}$ & $7.61_{a b}$ & $255.33_{a b c}$ & $20.84_{a b}$ & 12.30 & 4.83 & 3.67 \\
\hline O1 & 6.22 & $0.73_{b}$ & $8.47_{a}$ & $235.93_{a b c}$ & $21.26_{a b}$ & 11.13 & 3.79 & 3.73 \\
\hline $\mathrm{O} 2$ & 5.19 & $0.71_{b}$ & $7.37_{a b}$ & $255.92_{a b c}$ & $20.18_{a b}$ & 12.84 & 4.93 & 3.87 \\
\hline O3 & 5.37 & $0.81_{b}$ & $6.79_{a b c}$ & $253.21_{a b c}$ & $22.23_{a b}$ & 12.21 & 4.72 & 3.33 \\
\hline $\mathrm{O} 4$ & 5.66 & $0.80_{b}$ & $7.00_{a b c}$ & $278.92_{a b c}$ & $24.75 a$ & 11.38 & 4.93 & 4.28 \\
\hline O5 & 5.63 & $0.90_{b}$ & $6.32_{a b c}$ & $303.56_{a}$ & $21.53_{a b}$ & 14.43 & 5.39 & 3.36 \\
\hline
\end{tabular}

Arrange letters $\mathrm{a}, \mathrm{b}$ and $\mathrm{c}$ from large to small based on average values. Values in the same column followed by the same letter are not different $(p>0.05)$ according to a GLM protected LSD test. SOC: soil organic carbon; MBC: microbial biomass carbon; MBN: microbial biomass nitrogen.

\subsection{Soil Enzyme}

The $\beta$-glucosidase activity is shown in Figure 4a. CK and I1 presented significantly higher than did the others, except O1, whereas I3 presented significantly lower values than did CK, I1 and O1 $(p<0.05)$. AP was significantly correlated with $\beta$-glucosidase activity $(\mathrm{r}=0.451, p<0.01)$ (Table 4$)$. CK had the highest urease activity, and N5 had the lowest $(p<0.05$, Figure $4 \mathrm{~b})$, and urease was significantly correlated with AN $(r=0.451, p<0.01)$. O3 had significantly lower alkaline phosphatase activity than did CK and O5 $(p<0.05)$ (Figure 4 c), and alkaline phosphatase was significantly correlated with AN $(\mathrm{r}=0.535, p<0.01)$. Catalase activity is shown in Figure $4 \mathrm{~d} . \mathrm{N} 1, \mathrm{O} 4$ and $\mathrm{O} 5$ were significantly higher activity than did I1, I3 and O1 $(p<0.05)$, and the activity was highly significantly correlated with $\mathrm{MBC}(\mathrm{r}=0.775, p<0.01)$.

Table 4. The Pearson correlation coefficients between soil properties and enzyme activities.

\begin{tabular}{|c|c|c|c|c|c|c|c|c|c|c|c|}
\hline Soil Properties & $\mathrm{pH}$ & AN & AK & MBC & SOC & TN & AP & APL & $\beta$ & $\mathrm{Ur}$ & CAT \\
\hline $\mathrm{pH}$ & 1.000 & & & & & & & & & & \\
\hline AN & $-0.302 *$ & 1.000 & & & & & & & & & \\
\hline AK & -0.178 & 0.243 & 1.000 & & & & & & & & \\
\hline $\mathrm{MBC}$ & 0.034 & 0.057 & 0.000 & 1.000 & & & & & & & \\
\hline $\mathrm{SOC}$ & -0.215 & $0.386^{* *}$ & $0.396^{* *}$ & -0.091 & 1.000 & & & & & & \\
\hline $\mathrm{TN}$ & -0.155 & 0.620 ** & $0.321 *$ & 0.049 & $0.358 *$ & 1.000 & & & & & \\
\hline $\mathrm{AP}$ & -0.333 * & 0.285 * & -0.051 & -0.044 & 0.136 & -0.128 & 1.000 & & & & \\
\hline APL $\S$ & -0.256 & $0.535^{* *}$ & 0.237 & 0.242 & $0.343^{*}$ & 0.303 * & 0.263 & 1.000 & & & \\
\hline$\beta \S$ & -0.131 & 0.179 & 0.013 & -0.071 & 0.023 & -0.047 & 0.451 ** & 0.183 & 1.000 & & \\
\hline $\mathrm{Ur}^{\S}$ & -0.330 * & $0.372 * *$ & 0.200 & 0.055 & 0.221 & 0.185 & 0.548 ** & $0.422 * *$ & 0.116 & 1.000 & \\
\hline $\mathrm{CAT}^{\S}$ & -0.071 & 0.172 & -0.042 & $0.775^{* *}$ & -0.111 & 0.172 & -0.069 & 0.226 & 0.029 & -0.032 & 1.000 \\
\hline
\end{tabular}

${ }^{*} p=0.05$ (significant); ** $p=0.01$ (significant); ${ }^{\S}$ indicates the abbreviation for soil enzyme; ALP: alkaline phosphatase; $\beta$ : $\beta$-glucosidase; Ur: urease; CAT: catalase. 

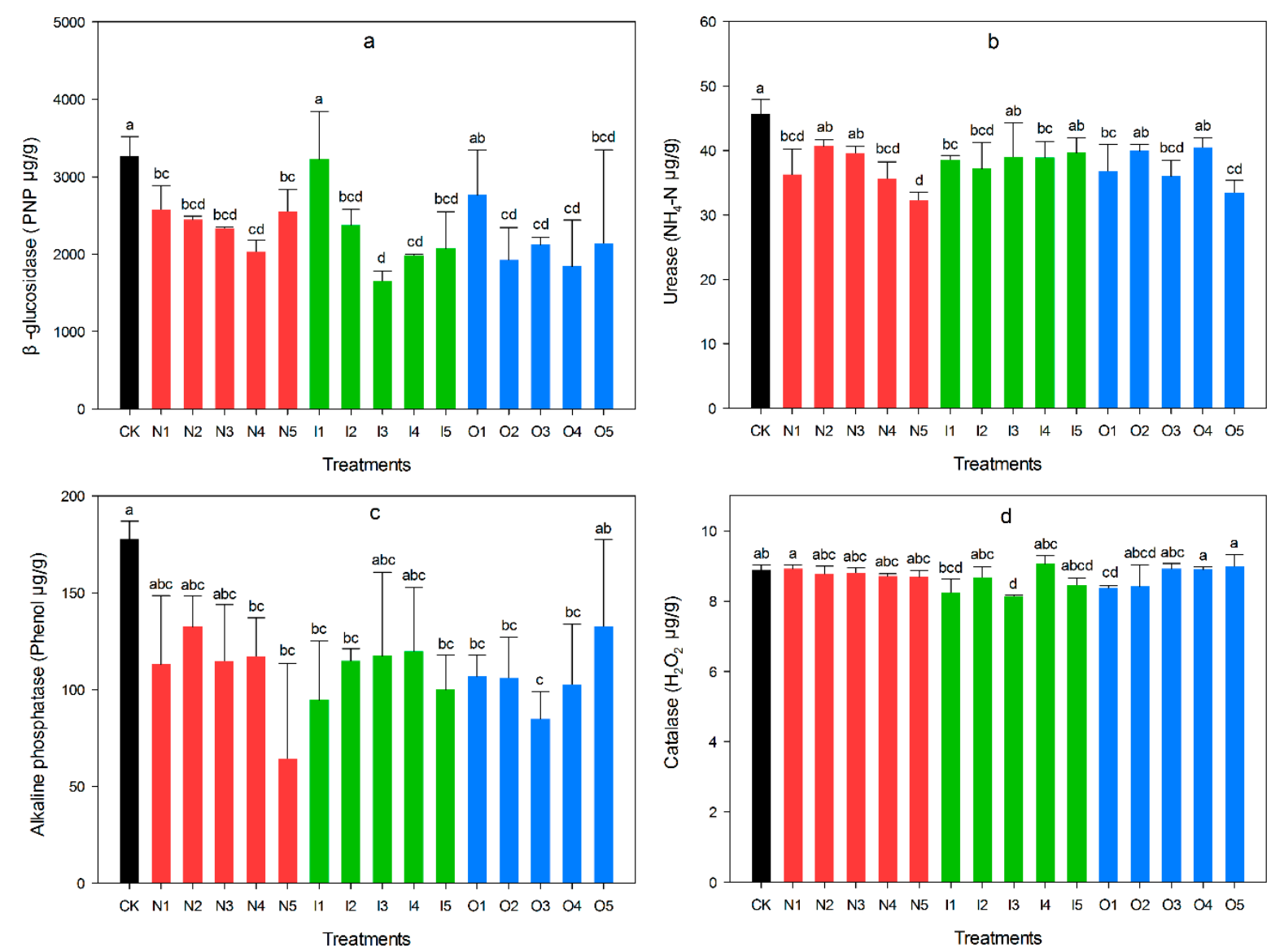

Figure 4. Changes of four enzyme activities in different set-aside patterns in spring, (a) $\beta$-glucosidase (b) urease (c) alkaline phosphatase (d) catalase. The black bar represented control (CK), red bar represented no management (N1-N5), the green bar represented only irrigation (I1-I5), the blue bar represented organic management (O1-O5).

\section{Discussion}

Management regimes showed more significant effects than did vegetation in short-term set-asides. Organic manure and chemical fertilizer clearly promoted the soil microbial alpha diversity of soil communities among plots. However, the organic manure was more effective than chemical fertilizer, because external nutrient resources and bacterial inputs altered intrinsic soil microbial communities [27].

No management presented more clustering than irrigation in terms of soil beta diversity. Manure seemed to cause clustering, with the exceptions of native plants and maize-soybean, possibly because those plants were less influenced by organic manure. According to the RDA, the microbial communities were susceptible to $\mathrm{pH}, \mathrm{AN}, \mathrm{TN}, \mathrm{MBN}$ and SOC. Considering the high local soil $\mathrm{pH}$, we suppose that the change in microorganisms is related to native soil conditions. In the absence of fertilizer, soil organic matter and nitrogen deficiency become important factors restricting soil microbial communities at this stage [28].

There were 23 major genera that changed in the soil (the relative abundance must be $>0.4 \%$ ), which represented significant changes. Nitrospira responds positively to high nitrogen availability and high nitrite oxidation potential [29]. In the short term, nitrification decreased in the set-aside areas because of fertilizer deficiency, and organic manure could relieve this reduction. This phenomenon could explain the loss of ammonium nitrogen in set-aside lands. However, Gp6 which is the predominate subgroup belonging to Acidobacteria, showed opposite results, in that the abundance decreased with fertilizer use. According to the previous research, Acidobacteria Gp4 and Gp6 
are more abundant in soils with relatively high SOC [30]. Our results confirm the relationships between Gp4, Gp6 and carbon, and the relationships were all opposite those with Nitrospira $(p<0.01)$. The unclassified Burkholderiales and unclassified Comamonadaceae may contribute to denitrification in farmlands; this phenomenon may be related to the biological control of natural soil diseases and could potentially promote plant growth [31,32]. Similarly, unclassified Burkholderiales and unclassified Comamonadaceae all showed opposite correlations with Nitrospira $(p<0.05)$. Therefore, manure can improve the nitrification but reduces both carbon aggregation and soil disease resistance. After multiple comparison tests, O1, I2, I4 and I5 were relatively more balanced than were the others, especially I5. We therefore suggest that only the irrigation management regime can maintain the short-term balance of soil microbial functions.

The differences of SOC were not significant so manure didn't show obvious effects during the stage [33]. Unmanaged maize-soybean resulted in relatively lower $\mathrm{C} / \mathrm{N}$ values compared with those of other management regimes. Therefore, this is consistent with previous research that abundant aboveground vegetation could cause increased nitrogen consumption [34]. Native plants displayed significantly lower MBC under only irrigation but relatively high $\mathrm{MBC}$ under no management, whereas $\mathrm{MBC}$ was modest under organic management. The microbial biomass $\mathrm{C} / \mathrm{N}$ ratio could reflect the proportion of fungi such that no management regime contributed to fungi in soil [35]. When CK was set as the comparison, the microbial biomass $\mathrm{C} / \mathrm{N}$ ratio indicates $\mathrm{N} 1-\mathrm{N} 4, \mathrm{I} 1, \mathrm{I} 4, \mathrm{O} 2$ and $\mathrm{O} 5$ were becoming dominated by fungi, and the others were becoming dominated by bacteria. The ratio of $\mathrm{MBC}$ to SOC could then be used to monitor changes in soil organic matter, and the normal range is $1-5 \%$ [36]. Here, we also set CK as the critical value. Based on the above results, we could obtain the following major types:

(i). Fungal dominant with more organic matter, which occurred in N2, I1 and I4.

(ii). Fungal dominant with less organic matter, which occurred in N1, N3, N4, O2 and O5.

(iii). Bacterial dominant with more organic matter, which occurred in N5, I2, I3 and O1.

(iv). Bacterial dominant with less organic matter, which occurred in $\mathrm{I} 5, \mathrm{O} 3$ and $\mathrm{O} 4$.

Considering that increased fungal efficiency is unsubstantiated, some studies have supported a greater carbon storage and slower carbon turnover [37,38]. We believe (iv) is necessary to enhance organic matter via manure supplementation. $\mathrm{N} 1$ and O5 exceeded normal levels (1-5\%), which may indicate the risk of organic matter deficiency. Therefore, organic matter levels should be monitored in the future. According to the current study, bacterial-dominated food webs do not cycle faster or replenish more carbon and nitrogen than do fungal-dominated food webs [39]. For this reason, we conservatively argue that (ii) and (iv) need organic matter supplementation. The addition of farmyard manure unexpectedly led to a lack of organic matter, except in the native plant treatment. When taking microbial communities together, our results confirm that O1, I2 and I4 are relatively stable set-aside patterns. It worth noting that group O didn't show any significant advantage over CK, which was also noted in some previous studies [40,41]. The major reason is no-tillage, the tillage method of our research, which encouraged the emergence of some weeds [42]. The boosting of vegetation may increase the deficiency of soil nutrients, which led to a decrease in microbial biomass and diversity [43]. Though the advantage of manure was not significant in the short-term, it still provided enough nutrients and changed soil microbiota which shouldn't be ignored in the set-aside. Mucoraceous fungi are the source of $\beta$-glucosidase [44]. Native plants were the best under the irrigation and organic management regimes. Although the accumulation of fungal pathogens could be caused by continuous sorghum cropping [45], the promotion of $\beta$-glucosidase generated by sorghum should not be ignored. The addition of leguminous vegetation weakened the advantage of sorghum and decreased the short-term activity of $\beta$-glucosidase.

Urease activity often indicates organic nitrogen mineralization and reflects the soil microbial processes and nitrogen supply capacity [46]. N5 and O5 showed significantly lower urease activity than did the other groups, confirming that the activity in alfalfa-dahurian wild rye was stimulated 
by irrigation. According to the empirical data, the plants of $\mathrm{O} 5$ presented lush growth; therefore, those plants appear to require more water and manure. Although urease is an important indicator of soil fertility, this enzyme converts organic nitrogen into ammonium nitrogen, and the rapid volatilization of ammonium nitrogen reduces nutrient components, resulting in the inefficient degradation of fertilizers [47].

According to the alkaline phosphatase results, tillage significantly influenced alkaline phosphatase activity, and no-till management promoted this activity [48]. However, we observed that conventional farming could also maintain a high level of alkaline phosphatase activity over time. Catalase presented highly significant positive correlations with microbial biomass. Catalase activity of I3 was significantly lower than that of group N; no other significant differences were observed in group I. A similar situation occurred for microbial alpha diversity.

Overall, set-asides did not benefit soil enzymes remarkably. Nevertheless, set-asides significantly affected microbial biomass and microbial communities. Farmyard manure likely led increased consumption of soil organic matter and enhanced nitrification, which were opposite effects to those observed under no management. However, some set-asides appeared more stable, including O1, I2 and I4. According to a cost-benefit analysis, soybean-maize and alfalfa-maize treatments with irrigation were the most economical and worth adopting. In other words, the use of native plants with farmyard manure is recommended for the most rapid improvement of arable land quality.

\section{Conclusions}

Our study has provided a new perspective of research on set-aside treatments in China, although set-asides were used for short period. The results did not show obvious benefits to soil enzymes in the short-term, but short-term set-asides could affect soil microbial functions via the microbial biomass and communities. At the same time, some set-asides showed more reliability. The selection of set-aside patterns (long or short term) should consider farmland background, and the deep understanding of set-aside management is important.

Supplementary Materials: The following are available online at www.mdpi.com/1660-4601/14/8/913/s1, Table S1: Summary of samples' sequence counts, Table S2: Simpson index of soil microbial community.

Acknowledgments: Thanks for supporting of Binzhou Land Improvement and Remediation Engineering Technology Research Center and all colleagues who had provide. This work was supported by the Major Program of National Social Science Foundation of China (grant numbers: 14ZDA039) and sponsor is Cifang Wu.

Author Contributions: Cifang Wu and Guangyu Li conceived and designed the experiments; Guangyu Li performed the experiments; Guangyu Li analyzed data; Cifang Wu contributed reagents/materials/analysis tools; Guangyu Li wrote the paper.

Conflicts of Interest: The authors declare no conflict of interest.

\section{References}

1. Cheng, F.; Wang, H.; Yun, W. Study on investigation and assessment of cultivated land quality grade in China. China Land Sci. 2014, 2, 75-82. (In Chinese)

2. Zentner, R.P.; Campbell, C.A. First 18 years of a long-term crop rotation study in southwestern Saskatchewan-yields, grain protein, and economic performance. Can. J. Plant Sci. 1988, 68, 1-21. [CrossRef]

3. Six, J.; Bossuyt, H.; Degryze, S.; Denef, K. A history of research on the link between (micro) aggregates, soil biota, and soil organic matter dynamics. Soil Till. Res. 2004, 79, 7-31. [CrossRef]

4. Altieri, M.A. The ecological role of biodiversity in agroecosystems. Agric. Ecosyst. Environ. 1999, 74, $19-31$. [CrossRef]

5. Henle, K.; Alard, D.; Clitherow, J.; Cobb, P.; Firbank, L.; Kull, T.; Mccracken, D.; Moritz, R.F.A.; Niemelä, J.; Rebane, M.; et al. Identifying and managing the conflicts between agriculture and biodiversity conservation in Europe-A review. Agric. Ecosyst. Environ. 2008, 124, 60-71. [CrossRef]

6. Xu, Z.; Xu, J.; Deng, X.; Huang, J.; Uchida, E.; Rozelle, S. Grain for green versus grain: Conflict between food security and conservation set-aside in China. World Dev. 2006, 34, 130-148. [CrossRef] 
7. Lam, H.-M.; Remais, J.; Fung, M.-C.; Xu, L.; Sun, S.S.-M. Food supply and food safety issues in China. Lancet 2013, 381, 2044-2053. [CrossRef]

8. Cassman, K.G. Ecological intensification of cereal production systems: Yield potential, soil quality, and precision agriculture. Proc. Natl. Acad. Sci. USA 1999, 96, 5952-5959. [CrossRef] [PubMed]

9. Doré, T.; Makowski, D.; Malézieux, E.; Munier-Jolain, N.; Tchamitchian, M.; Tittonell, P. Facing up to the paradigm of ecological intensification in agronomy: Revisiting methods, concepts and knowledge. Eur. J. Agron. 2011, 34, 197-210. [CrossRef]

10. Bommarco, R.; Kleijn, D.; Potts, S.G. Ecological intensification: Harnessing ecosystem services for food security. Trend Ecol. Evolut. 2013, 28, 230-238. [CrossRef] [PubMed]

11. Rusinamhodzi, L.; Corbeels, M.; Nyamangara, J.; Giller, K.E. Maize-grain legume intercropping is an attractive option for ecological intensification that reduces climatic risk for smallholder farmers in central Mozambique. Field Crop Res. 2012, 136, 12-22. [CrossRef]

12. Zhou, L.X.; Ding, M. Soil microbial characteristics as bioindicators of soil health. Biodivers. Sci. 2007, 15, $162-171$.

13. Yusuf, A.; Abaidoo, R.; Iwuafor, E.; Olufajo, O.; Sanginga, N. Rotation effects of grain legumes and fallow on maize yield, microbial biomass and chemical properties of an Alfisol in the Nigerian savanna. Agric. Ecosyst. Environ. 2009, 129, 325-331. [CrossRef]

14. Lin, X.G.; Feng, Y.Z.; Zhang, H.Y.; Chen, R.R.; Wang, J.H.; Zhang, J.B.; Chu, H.Y. Long-term balanced fertilization decreases arbuscular mycorrhizal fungal diversity in an arable soil in North China revealed by 454 pyrosequencing. Environ. Sci. Technol. 2012, 46, 5764-5771. [CrossRef] [PubMed]

15. Nivelle, E.; Verzeaux, J.; Habbib, H.; Kuzyakov, Y.; Decocq, G.; Roger, D.; Lacoux, J.; Duclercq, J.; Spicher, F.; Nava-Saucedo, J.-E. Functional response of soil microbial communities to tillage, cover crops and nitrogen fertilization. Appl. Soil Ecol. 2016, 108, 147-155. [CrossRef]

16. Jusselme, M.D.; Miambi, E.; Mora, P.; Diouf, M.; Rouland-Lefèvre, C. Increased lead availability and enzyme activities in root-adhering soil of Lantana camara during phytoextraction in the presence of earthworms. Sci. Total Environ. 2013, 445, 101-109. [CrossRef] [PubMed]

17. Brussaard, L.; de Ruiter, P.C.; Brown, G.G. Soil biodiversity for agricultural sustainability. Agric. Ecosyst. Environ. 2007, 121, 233-244. [CrossRef]

18. Myers, R. Nitrogen Management of Upland Crops: From Cereals to Food Legumes to Sugarcane; CAB International: Wallingford, UK, 1988.

19. Angenent, L.T.; Kelley, S.T.; Amand, A.S.; Pace, N.R.; Hernandez, M.T. Molecular identification of potential pathogens in water and air of a hospital therapy pool. Proc. Natl. Acad. Sci. USA 2005, 102, 4860-4865. [CrossRef] [PubMed]

20. Wang, Q.; Garrity, G.M.; Tiedje, J.M.; Cole, J.R. Naive bayesian classifier for rapid assignment of rRNA sequences into the new bacterial taxonomy. Appl. Environ. Microbiol. 2007, 73, 5261-5267. [CrossRef] [PubMed]

21. Brookes, P.C.; Landman, A.; Pruden, G.; Jenkinson, D.S. Chloroform fumigation and the release of soil nitrogen: A rapid direct extraction method to measure microbial biomass nitrogen in soil. Soil Biol. Biochem. 1985, 17, 837-842. [CrossRef]

22. Vance, E.; Brookes, P.; Jenkinson, D. An extraction method for measuring soil microbial biomass C. Soil Biol. Biochem. 1987, 19, 703-707. [CrossRef]

23. Joergensen, R.G. The fumigation-extraction method to estimate soil microbial biomass: Calibration of the $k_{\mathrm{EC}}$ value. Soil Biol. Biochem. 1996, 28, 25-31. [CrossRef]

24. Dick, R.P.; Breakwell, D.P.; Turco, R.F.; Doran, J.W.; Jones, A.J. Soil enzyme activities and biodiversity measurements as integrative microbiological indicators. Soil Sci. Soc. Am. J. 1996, 49, 247-271.

25. Hoffmann, G.; Teicher, K. Ein kolorimetrisches verfahren zur bestimmung der ureaseaktivität in Böden. J. Plant Nutr. Soil Sci. 1961, 95, 55-63. [CrossRef]

26. Hoffmann, G. Eine photometrische methode zur bestimmung der phosphatase-aktivität in Böden. J. Plant Nutr. Soil Sci. 1968, 118, 161-172. [CrossRef]

27. Torsvik, V.; Øvreås, L. Microbial diversity and function in soil: From genes to ecosystems. Curr. Opin. Microbiol. 2002, 5, 240-245. [CrossRef]

28. Scheu, S. Changes in microbial nutrient status during secondary succession and its modification by earthworms. Oecologia 1990, 84, 351-358. [CrossRef] [PubMed] 
29. Attard, E.; Poly, F.; Commeaux, C.; Laurent, F.; Terada, A.; Smets, B.F.; Recous, S.; Roux, X.L. Shifts between Nitrospira- and Nitrobacter-like nitrite oxidizers underlie the response of soil potential nitrite oxidation to changes in tillage practices. Environ. Microbiol. 2010, 12, 315-326. [CrossRef] [PubMed]

30. Sul, W.J.; Asuming-Brempong, S.; Wang, Q.; Tourlousse, D.M.; Penton, C.R.; Deng, Y.; Rodrigues, J.L.; Adiku, S.G.; Jones, J.W.; Zhou, J. Tropical agricultural land management influences on soil microbial communities through its effect on soil organic carbon. Soil Biol. Biochem. 2013, 65, 33-38. [CrossRef]

31. Van, V.T.; Berge, O.; Ke, S.N.; Balandreau, J.; Heulin, T. Repeated beneficial effects of rice inoculation with a strain of Burkholderia vietnamiensison early and late yield components in low fertility sulphate acid soils of Vietnam. Plant Soil 2000, 218, 273-284. [CrossRef]

32. Yoshida, M.; Ishii, S.; Otsuka, S.; Senoo, K. Temporal shifts in diversity and quantity of nirS and nirK in a rice paddy field soil. Soil Biol. Biochem. 2009, 41, 2044-2051. [CrossRef]

33. Zaller, J.G.; Köpke, U. Effects of traditional and biodynamic farmyard manure amendment on yields, soil chemical, biochemical and biological properties in a long-term field experiment. Biol. Fert. Soils 2004, 40, 222-229. [CrossRef]

34. Hu, S.; Chapin, F.S., III; Firestone, M.K.; Field, C.B.; Chiariello, N.R. Nitrogen limitation of microbial decomposition in a grassland under elevated $\mathrm{CO}_{2}$. Nature 2001, 409, 188-191. [CrossRef] [PubMed]

35. Campbell, C.A.; Biederbeck, V.O.; Zentner, R.P.; Lafond, G.P. Effect of crop rotations and cultural practices on soil organic matter, microbial biomass and respiration in a thin Black Chernozem. Can. J. Soil Sci. 1991, 71, 363-376. [CrossRef]

36. Sparling, G.P. Ratio of microbial biomass carbon to soil organic carbon as a sensitive indicator of changes in soil organic matter. Soil Res. 1992, 30, 195-207. [CrossRef]

37. Thiet, R.K.; Frey, S.D.; Six, J. Do growth yield efficiencies differ between soil microbial communities differing in fungal:bacterial ratios? Reality check and methodological issues. Soil Biol. Biochem. 2006, 38, 837-844. [CrossRef]

38. De Graaff, M.-A.; Classen, A.T.; Castro, H.F.; Schadt, C.W. Labile soil carbon inputs mediate the soil microbial community composition and plant residue decomposition rates. New Phytol. 2010, 188, 1055-1064. [CrossRef] [PubMed]

39. Rousk, J.; Frey, S.D. Revisiting the hypothesis that fungal-to-bacterial dominance characterizes turnover of soil organic matter and nutrients. Ecol. Monogr. 2015, 85, 457-472. [CrossRef]

40. Lupwayi, N.Z.; Lea, T.; Beaudoin, J.L.; Clayton, G.W. Soil microbial biomass, functional diversity and crop yields following application of cattle manure, hog manure and inorganic fertilizers. Can. J. Soil Sci. 2005, 85, 193-201. [CrossRef]

41. Zhen, Z.; Liu, H.; Wang, N.; Guo, L.; Meng, J.; Ding, N.; Wu, G.; Jiang, G. Effects of manure compost application on soil microbial community diversity and soil microenvironments in a temperate cropland in China. PLoS ONE 2014, 9, e108555. [CrossRef] [PubMed]

42. Chauhan, B.S.; Johnson, D.E. Influence of tillage systems on weed seedling emergence pattern in rainfed rice. Soil Till. Res. 2009, 106, 15-21. [CrossRef]

43. Inselsbacher, E.; Hinko-Najera Umana, N.; Stange, F.C.; Gorfer, M.; Schüller, E.; Ripka, K.; Zechmeister-Boltenstern, S.; Hood-Novotny, R.; Strauss, J.; Wanek, W. Short-term competition between crop plants and soil microbes for inorganic N fertilizer. Soil Biol. Biochem. 2010, 42, 360-372. [CrossRef]

44. Kotroczó, Z.; Veres, Z.; Fekete, I.; Krakomperger, Z.; Tóth, J.A.; Lajtha, K.; Tóthmérész, B. Soil enzyme activity in response to long-term organic matter manipulation. Soil Biol. Biochem. 2014, 70, 237-243. [CrossRef]

45. Guenzi, W.; McCalla, T. Phenolic acids in oats, wheat, sorghum, and corn residues and their phytotoxicity. Agron. J. 1966, 58, 303-304. [CrossRef]

46. Nannipieri, P.; Giagnoni, L.; Renella, G.; Puglisi, E.; Ceccanti, B.; Masciandaro, G.; Fornasier, F.; Moscatelli, M.C.; Marinari, S. Soil enzymology: Classical and molecular approaches. Biol. Fert. Soils 2012, 48, 743-762. [CrossRef] 
47. Kiss, S.; Simihaian, M. Improving Efficiency of Urea Fertilizers by Inhibition of Soil Urease Activity; Springer: Berlin, Germany, 2013.

48. Hu, J.; Yang, A.; Wang, J.; Zhu, A.; Dai, J.; Wong, M.H.; Lin, X. Arbuscular mycorrhizal fungal species composition, propagule density, and soil alkaline phosphatase activity in response to continuous and alternate no-tillage in Northern China. Catena 2015, 133, 215-220. [CrossRef] 